\title{
Improvement And Development Of The Motiva- tion System In The Occupational And Industrial Safety Field
}

\author{
Arkhip Pavlov ${ }^{1 *}$, and Dmitrij Gavrilov ${ }^{1}$ \\ ${ }^{1}$ JSC “VostNII” 650002, 3 Institutskaya Str., Kemerovo, Russia
}

\begin{abstract}
This paper discusses one of the main problems in labour and industrial management in the occupational and industrial safety field - motivation to work safely. The problem is complex and should be solved by a set of measures, where the assignment of responsibility to employees for the results of their work is absent, including in the field of labour protection and industrial safety. In accordance with the obligatory management principles, employees' work resolves to the strict implementation of the actions prescribed by the regulations. The responsibility for the negative result rests with the person who enacted or instructs employees. Thus, the employee is practically exempt from responsibility for the final result. One of the possible solutions to this problem is to put an assignment of responsibility on the employees for the results of their activities also in the occupational and industrial safety field. This is illustrated by the experience of other states, particularly of Australia. In conclusion suggestions for improvement and development of the motivation system in the field of occupational and industrial safety.
\end{abstract}

\section{Introduction}

Article 212 of the Labour Code of the Russian Federation stipulates that "the duties in respect of ensuring labour safety in the organization are imposed on the employer"; next follows a list of many conditions that the employer must ensure.

Article 9 of the Federal Law "On Industrial Safety of Hazardous Production Facilities" begins with the words: "An organization operating a hazardous production facility shall", and then there is a multi-page recitation of duties. That said, in accordance with Article 216 of the Criminal Code, "violation of safety rules during mining, building or any other activities, if this has involved by negligence the infliction of grave injury to human health or major material damage, shall be punishable" either by a fine or by deprivation of liberty.

Here, it is appropriate to express a reservation that both the Labour Code of the Russian Federation and the Federal Law "On Industrial Safety of Hazardous Production Facilities" are not safety rules as such. Such a discrepancy of the legislation on labour protection and industrial safety with the Criminal Code is due to the fact that Article 216, like many other

\footnotetext{
* Corresponding author: a.zakirova@nc-vostnii.ru
} 
articles of the Criminal Code, was formulated at a time when these legislative acts on labour protection and industrial safety did not yet exist. There were only industry-specific safety rules.

At the same time, Article 216 of the Criminal Code is in force. When an event falling under this article occurs, there arises a problem of justifying the causal relation between the action or inaction of an employee and the accident that caused such "grave injury to human health or major damage." However, when identifying such dependence, few turn to the obligations of the 'employer' stipulated by the Labour Code of the Russian Federation and the duties of the 'organization' contained in the Federal Law "On Industrial Safety of Hazardous Production Facilities", while the Criminal Code is aimed at a particular responsible person.

This is the present-day problem of placing responsibility for "grave injury to human health or major damage" through negligence.

\section{Materials and methods}

When investigating the circumstances that led to "grave injury to human health or major damage", the picture of the emergence and development of the dangerous event is reproduced in the first place. For this purpose, the network model of the processes of formation and manifestation of the danger in all casual relations is appears most convenient. In this case, all the reasons can be taken into account: technical, organizational, and personal. All persons involved in the analyzed event are identified, and the analysis often covers all periods of the operational life of the production facility, starting from the stage of design.

With such approach, the investigation ends with the identification of the inadequate actions or inaction of particular employees, which resulted in "grave injury to human health or major damage". But in most cases, the investigation covers only immediate performers, middle-ranking managers and specialists or blue-collar professionals. Such an investigation of the accidents often does not bring light the causes of inadequate actions or inactions of the immediate performers and does not ask why the employees did not perform their duties or why they performed their duties improperly.

To find answers to such questions, it is necessary to investigate the production management system and personnel management system, including labour protection and industrial safety, since such answers as 'did not want to' or 'could not' reflect, first of all, the presence of defects in the systems of production management, personnel management and labour safety management, and this is the sphere of motivation and organization of labour that belongs to the senior executives and specialists and the top management of the organization.

However, this is yet to come. As a result, the statistics of criminal responsibility based on the results of the accident investigations still includes only managers and specialists of the middle level of mining management.

The existing domestic judicial practice appears to correspond to the previous state system. Today, the state system is different, many issues are seen in the other way; the legislation on labour protection and industrial safety was adopted. Therefore, different mechanisms for employee motivation in the field of labour protection and industrial safety should also be applied.

Addressing this issue, it must be recognized that judicial practice largely depends on the perfection of legislation, the efficiency of accident investigation and investigative actions, guided by such precedents. Let us consider a precedent from the foreign experience of legal proceedings following the investigation of an accident in a mining company, since the current Russian legislation on labour safety was largely based on the international standards of health protection of personnel at industrial enterprises. 
The Gretley Coal Mine Disaster

Case. Gretley management obtained from the Department of Mineral Resources some old plans that purported to indicate the location of the earlier workings of an adjacent closed mine. The Department of Mineral Resources provided copies of the old workings plan, but these plans were wrong.

Based on the department's data, Gretley management organized excavations of a new section of the mine. Miners inadvertently broke through into the flooded workings of an adjacent abandoned mine, and four miners died in the inrush of water.

Such accidents occur in mining. What is of interest here is the judicial decisions made on this case, which give an answer to the question: when do the managers and specialists carry the responsibility? Consider this in more detail [1-5].

Defence. The coal company claimed that the mining operations were carried out according to plans presented by the Department of Mineral Resources, which, as it turned out, indicated the location of the old workings incorrectly.

Judgment. The court rejected the company's claim, arguing that the company may have relied on the information obtained from the Department of Mineral Resources and considered it accurate, but this did not exempt the company from the obligation to safely conduct mining operations; the company had to ensure the accuracy of plans submitted by the Department of Mineral Resources.

Based on the investigation, the court rules that in accordance with the Mining and Quarrying Safety and Health Act of 1999 and the Coal Mining Safety and Health Act of 1999:

1. The company has the right to rely on information received from outside organizations, institutions and individuals, considering it to be accurate, but it does not exempt the company from the obligation to provide and guarantee the safety of works. The company must verify the accuracy of the information received.

2. There are two grounds for assigning responsibility to employees and recognizing their culpability:

- employee's having opportunity to influence the company's policies,

- employee's failure to perform or improper performance of all possible actions to prevent the accident.

3. The grounds for dismissing the accusations towards the employee are the absence of conditions and opportunities for their influence on the management of the company in order to prevent the accident.

4. If the company is found culpable, then the accusation is presented to the chief executive officer.

The chief executive officer of the company is a person who:

- is one of the company's directors,

- takes part in the management of the company, regardless of the name of their position, and is the immediate head of the company.

5. Responsibility must be imposed on those people whose actions or inactions have led to violations of the company's activities, and such actions or inactions should be considered complicity in the activities that led to such violations [6-10].

6. 'To take part in the management of the company' means to bear responsibility for actions or inactions that led to violations of the company's activities.

The actions of a particular person that played a role in the activities of the company may include:

- advice given to the company management;

- participation in decision-making;

- execution of decisions received from the company management.

7. The actions entailing responsibility for the management of the company are:

- participation in the budget planning; 
- participation in drawing up the production plan;

- participation in the management meetings;

- control over the implementation of decisions;

- responsibility for certain functions of the company;

- organization and conduct of audits;

- development and approval of the company plans;

- signing of reports.

8. 'Advisor' is deemed involved into the management of the company:

- if the executive officials of the company use their advice to make decisions and when such pieces of advice play a leading role in making corporate decisions;

- if such advisor at least partially implement the decision, affecting the company as a whole;

- if such advisor makes decisions that purport to decisions related to the violation in question, although they may not affect the company as a whole.

9. The statement of any employee about their innocence must be supported by evidence that they had no influence on the prevention of the accident.

10. The specialist is not responsible for the accuracy of the information presented to them (the initial data), but is responsible for the accuracy of any production and technical design document developed by them based on such information.

11. Anyone who was able to prevent the accident but did not make proper effort to do so, is recognized as culpable.

12. The director of the mine is responsible for a wide range of issues related to occupational safety, and it is not difficult to prove that the managers of the mine took immediate part in the management of the enterprise.

The court dismissed the plea of non-guilty presented by two company executives and the mine surveyor, having decided that they took part in the management of the company, since it was not established that they had no opportunity to influence the company's policy, and also that they did not take proper actions to prevent the accident.

The mine surveyor of the Gretley mine claimed that he could not be held responsible for the accuracy of the documents made by the previous surveyor or signed by another surveyor. But, according to the court's opinion, he certified the accuracy of plans drawn up by him or under his direction with his signature, and it was exactly his signature on the plans that made him responsible. The surveyor was able to verify in the mining plans, but he did not take proper efforts to study the location of the old mine workings [11-15].

\section{Results and discussion}

Firstly, in accordance with the Criminal Code of the Russian Federation, the mechanism and the logic of assignment of guilt in labour protection and industrial safety issues is based primarily on the provisions of the rules for the safe conduct of mining, construction and other works. These rules regulate the activities of performers of mining, construction and other works and are violated mainly by the middle-ranking managers and specialists and blue-collar professionals.

Secondly, both the Criminal Code of the Russian Federation and the Industrial Safety Rules in the sectors of Russian economy were adopted much earlier than the current legislation of the Russian Federation on labour protection and industrial safety, which largely relies on foreign labour protection experience. As a result, considerable obligations were imposed on both the employer and the organization, but a mechanism that would impose responsibility for the implementation of such obligations has not been formed yet. The exist- 
ing mechanism of imposing responsibility for violating the Safety Rules appears to be impracticable.

The problem arises from the fact that there is no efficient mechanism to motivate employees to work safely and efficiently in the interest of the whole business. It should be noted that the problem of motivating employees to work safely, as any other problem, cannot be solved by a single action. The solution can be achieved by implementing a package of measures. The problem of motivating employees to work safely demonstrates the absence of one of the motivation methods - the imposition on the employee of all forms of responsibility, including criminal liability, for any negative outcome of their actions or inaction. Virtually having the right of operational management of the production activities on the facility under their control, the employee remains free from liability for any negative outcome of his actions or inactions. This, first, violates the balance of rights and responsibilities, and, second, a rather effective mechanism for motivation as criminal liability is ignored.

Thirdly, when assigning responsibility for non-fulfilment or improper fulfilment of labour protection and safety legislation in the judicial practice of many foreign countries, the courts are guided by the following provisions:

- culpability for the accident lies with the company,

- if the company is found culpable, then the accusations are presented to the chief executive officer,

- a chief executive officer of the company is the person who takes part in the management of the company, regardless of the name of their position, and is the immediate head of the company,

- 'to take part in the management of the company' means to bear responsibility for actions or inactions that led to violations of the company's activities.

\section{Conclusions}

1. The logic of assigning responsibility is rather simple: so many duties, so much responsibility. If, in accordance with Article 212 of the Labour Code of the Russian Federation, "the duties in respect of ensuring labour safety in the organization are imposed on the employer", the responsibility for ensuring safe working conditions and labour protection in the organization shall also borne by the employer. In accordance with Article 20 of the Labour Code the Russian Federation, the employer is an individual or a legal entity (organization) entering labour relations with the employee and having the right to enter into employment agreements. An individual, in this case, usually acts an individual entrepreneur, white the head of the organization acts on behalf of the legal entity.

2. Following the terminology used in the Labour Code of the Russian Federation, the industrial safety requirements stipulated in Item 1 Article 9 of the Federal Law "On Industrial Safety of Hazardous Production Facilities" and addressed to the organizations, should be seen as addressed to a legal person, employer, head of the organization.

3. The mechanism of imposing criminal liability for violations of labour protection and industrial safety legislation should be streamlined with the current legislation of the Russian Federation on occupational and industrial safety.

4. Harmonization of Russian legislation on labour protection and industrial safety with the international legislation demonstrates the need in improving and updating the mechanisms imposing responsibility for occupational and industrial safety based on international experience. 
5. Responsibility should be imposed on those people whose actions or inactions have led to violations of the company's activities, and such actions or inactions should be considered complicity in the activities that led to such violations.

6. The principle that 'implementation of the rules and norms cannot be sufficient grounds of non-culpability for any negative outcome' should be applied. The concept that everyone is obliged to take every possible action of those actions that are necessary, regardless of whether it is stipulated by the rules or not, should be made a legal norm.

7. Terms and definitions:

- Competence is the professional ability to do the assigned work;

- Competency is the right to express professional ability under one's personal responsibility, according to the principle: if you do, take the consequences.

\section{References}

1. F. Hopkins, Managing Major Hazards: The lessons of the Moura Mine Disaster, (Sydney, Allen and Unwin, 1999)

2. J. L. Massie, J. Douglas, Managing: A Contemporary Introduction, (Englewood Cliffs: Simon \& Schuster Company, 1992)

3. R.J. Schonberger, Japanese manufacturing techniques: Nine Hidden Lessons in Simplicity, 55 (New York, The Free Press: a division of Macmillan Publishing Co., 1982)

4. F. Luthans, Organizational Behavior, (New York: McGraw-Hill, 1989)

5. W. G. Ouchi, Theory Z: How American Business Can Meet the Japanese Challenge, 244 (New York: Avon Books, 1981)

6. Queensland Mining Industry Health and Safety Conference, 206 (collection of papers. Townsvill, Queensland, Australia, 2005)

7. K. Yin. Robert, Case Study Research: Design and Methods (SAGE Publications. California, 1989)

8. I Masaaki, G. A. Kaizen, Commonsense, Low-Cost Approach to Management, (New York, McGraw-Hill, 1997)

9. J. Womack, D. Jones, Lean Thinking: Banish Waste and Create Wealth in Your Corporation (New York, Simon \& Schuster, 2003)

10. M. Rother, J. Shook, Learning to See: Value Stream Mapping to Add Value and Eliminate Muda, (Brookline, MA, Lean Enterprise Institute, 1999)

11. J.P. Kotter, Leading Change, (Boston, MA, Harvard Business School Press, 1996)

12. B. Emiliani, Better Thinking, Better Results: Using the Power of Lean as a Total Business Solution, (Kensington, CT, The Center for Lean Business Management, 2002)

13. J.H. Dyer, Collaborative Advantage: Winning Through Extended Enterprise Supplier Networks, (New York, Oxford University Press, 2000)

14. H. Emerson, The twelve principles of efficiency, (New York, Engineering magazine, 1912)

15. T. Fujimoto, The Evolution of a Manufacturing System at Toyota, (NY, Oxford University Press, 1999) 